\title{
SHORT-TERM VERSUS LONG-TERM INTERESTS: CAPITAL STRUCTURE WITH MULTIPLE INVESTORS*
}

\author{
Erik Berglöf and ERnst-Ludwig von Thadden
}

\begin{abstract}
We study the problem of financial contracting and renegotiation between a firm and outside investors when the firm cannot commit to future payouts, but assets can be contracted upon. We show that a capital structure with multiple investors specializing in short-term and long-term claims is superior to a structure with only one type of claim, because this hardens the incentives for the entrepreneur to renegotiate the contract ex post. Depending on the parameters, the optimal capital structure also differentiates between state-independent and state-dependent longterm claims, which can be interpreted as long-term debt and equity.
\end{abstract}

\section{INTRODUCTION}

Most firms have more than one investor and issue more than one type of financial claim. These claims differ, among other things, in maturity, payout contingencies, security interests, and priority in bankruptcy. Investors usually specialize in particular claims, e.g., by holding only short-term debt or only equity in a firm. In case firms are financially distressed, short-term creditors rarely forgive debt, while concessions often are made by subordinated long-term claim-holders. This paper attempts to explain these and other observations by asking how rational investors design capital structure; i.e., how they allocate rights to returns and what rules they specify to enforce these rights.

We study the problem of a firm seeking to raise capital against the promise to pay investors back out of future returns. When these returns are not verifiable in court, the promise must be made credible. In practice, debt contracts often solve this problem by giving investors, in case repayment promises are not met, the right to liquidate or force the sale of assets that are easier to verify. Typically, such assets exhibit a certain degree of firm specificity, and hence are of less value outside the firm than for the generation of future returns within the firm. Therefore, as emphasized by Hart and Moore [1989, 1994], liquidation potentially hurts not

\footnotetext{
*We are grateful to Patrick Bolton, Mathias Dewatripont, Douglas Diamond, Oliver Hart, Martin Hellwig, Andrei Shleifer, Jean Tirole, Sheridan Titman, Walter Torous, and two anonymous referees for suggestions or helpful discussions. Von Thadden thanks Stanford University for their hospitality. Financial support by the Bank of Sweden Tercentenary Fund (Berglöf), Swedish Banking Research Institute, and the PAI program (Grant 26) of the Belgian government, and Schweizerischer Nationalfonds Grant 8210-033262 (Von Thadden) is gratefully acknowledged.

c 1994 by the President and Fellows of Harvard College and the Massachusetts Institute of Technology.

The Quarterly Journal of Economics, November 1994
} 
only the firm, but also the investors and creates room for renegotiations. This strengthens the firm's incentives to default strategically ex post, and thus weakens its commitment ability ex ante. We analyze how the choice between one or more investors and the allocation of liquidation rights and intertemporal return rights between investors affect the ex post renegotiation.

We show that in general the firm will choose to have more than one (class of) investor(s) and that investors separate their claims across time and states of nature, with one investor holding secured short-term claims and another junior long-term claims. If the firm is doing well in the short run, the short-term creditor is repaid, and long-term claim-holders receive all future returns. If the firm is unable to repay in the short run, the short-term creditor forces the firm to transfer or sell part of its assets. The maturity of her remaining claims is extended at the expense of some (not necessarily all) junior long-term claim-holders.

The principal reason for this separation is that the ex post bargaining position of an investor with short-term claims is weaker if she also has long-term claims because she internalizes the impact of her actions on future revenues. On the other hand, separating outside claims over time creates an externality on the side of the short-term investor, which strengthens her bargaining power if the firm should attempt to default. Separation of claims across highand low-cash-flow states-i.e., making long-term claims junior to unpaid short-term debt-further discourages strategic default, by giving the short-term investor an extra incentive to be tough with the firm.

In some parameter constellations-when the investment is sufficiently profitable or when the share of tangible assets in the firm is sufficiently high-separation of claims across time and states actually provides maximum deterrence from strategic default, namely zero rents from renegotiation. Therefore, not all long-term claims are subordinated to unpaid short-term claims; in addition to the state-contingent long-term claim, the optimal capital structure contains a second, safe, long-term claim (a bond). In the complementary set of parameters-when the investment is less profitable - only two types of claims (short-term secured claims and state-contingent long-term claims) are issued. In our analysis the state-contingent long-term claim (equity) plays the role of "strategic slack" in the spirit of Dewatripont and Tirole [1994]: payouts are allocated to the firm and the short-term creditor in order to optimize incentives, and the equity-holders 
balance the account. Our analysis goes beyond that of Dewatripont and Tirole on this point, by introducing long-term debt (the state-independent long-term claim) and characterizing the constellations in which this additional claim will be optimally issued.

Our findings are consistent with recent empirical work on bankruptcy and reorganization in the United States by Gilson, John, and Lang [1990] and Asquith, Gertner, and Scharfstein [1994]. These studies show how capital structure affects how firms fare in financial distress. In particular, in their examination of U. S. junk bond issuers, Asquith, Gertner, and Scharfstein show that when companies are distressed, banks, who hold most of the senior debt, virtually never forgive principal and rarely provide refinancing outside of bankruptcy. However, extending maturity on troubled loans is quite common ( 28 of the 76 cases in the sample). Concessions, to the extent that they are given, come from subordinated bondholders, typically through exchange offers. ${ }^{1}$ Here, postponement, although it may reduce creditor returns to some extent, is more favorable to senior debt-holders than forgiveness, because it comes at the expense of long-term claim-holders. The theory developed in this paper predicts such postponement if the firm is in financial distress, and predicts that it is accompanied by asset sales and partial liquidations. Indeed, there is empirical evidence that forced asset sales to pay off senior creditors are an important feature of financial distress. The more commercial bank debt a distressed firm has, the more likely it is that asset sales are used to repay debt [Brown, James, and Mooradian 1993]. Our analysis suggests that this emphasis of private debt-holders on short-term goals, at the expense of subordinated long-term claimholders, may be desirable ex ante. It allows debtors to commit to future payouts in a world where cash flows are difficult to verify. In this respect, "short-termism" may be of strategic value.

The existing literature on default and bankruptcy usually takes the allocation of claims as exogenous and derives implications for liquidation, rescheduling of debt, and other issues at the incidence of default, given this structure (for examples, see Bulow and Shoven [1978], Gertner and Scharfstein [1991], and Franks

1. One of the main interests of Gilson, John, and Lang [1990] and Asquith, Gertner, and Scharfstein [1994] is to compare informal reorganization and formal bankruptcy as responses to financial distress. Our model does not allow for this distinction: firms in our model survive financial distress, only the extent of liquidation or forced asset sales in default is of interest. Incorporating the possibility of bankruptcy in the present model, e.g., by letting first-period returns be informative about future returns, is an interesting line of future research. 
and Nyborg [1993]. Building on the recent research on financial contracting, we depart from this approach by emphasizing the strategic relationship between short-term and long-term, and between junior and senior, financial claims in the overall problem of security design, i.e., at a stage of the interaction between firm and investors where the parties consider default only one future possibility.

Unlike previous work on capital structure, the security design literature does not assume the existence of particular financial instruments, such as debt and equity, but rather tries to generate these instruments and combinations of them as optimal contracts (for surveys of this literature see Harris and Raviv [1992] and Hart [1993]).

The rationale for multiple outside investors holding different financial claims has only recently begun to be explored. Williams [1989] proposes a model in which company returns-as in our model, though in a static setting - have a verifiable ("assets") and an unverifiable ("cash") component, and the optimal contract promises the (single) investor a fixed cash payment plus a fraction of the assets. Zender [1991] shows how the traditional return streams of fixed repayments and residual claims can arise endogenously if investors are cash constrained. ${ }^{2}$

Related work on the allocation of returns and control rights among several investors is that of Diamond [1992]. As in the present paper, short-term and long-term debt are held by different investors, and short-term debt is senior to long-term debt. However, the existence of multiple investors is assumed rather than explained, because different investors have different liquidation abilities. Furthermore, as in Hart and Moore [1993], Diamond assumes long-term investors to be dispersed, making renegotiation more difficult. This assumption is not made in our paper.

Dewatripont and Tirole [1994] consider a model of capital structure with multiple investors holding debt and equity. In their analysis the firm's capital structure is designed to provide both insiders and outsiders with incentive schemes. Managers are

2. More precisely, the capital structure in Zender [1991] consists of debt and inside equity (as in Bergman and Callens's [1991] analysis of dynamic debt renegotiation, there are only two players, one of whom obtains residual returns and holds control).

Winton [1990], somewhat orthogonal to our approach, approaches the multiinvestor problem with a model of costly state verification. He generates a capital structure with multiple investors holding instruments of different priority as a means of economizing on verification costs. 
induced to maximize firm value, whereas outside investors are given incentives to intervene when managerial compensation schemes fail. Although this focus on incentives is different from ours, their paper is similar in the identification of equity as a "soft claim."3

In work most closely related to ours, Bolton and Scharfstein [1992] have studied the value of contracting with several creditors in a model of contract renegotiation. ${ }^{4}$ Their main argument is that, when renegotiation is inefficient, e.g., because information is asymmetrically distributed, two creditors may extract more cash flows from the firm than one creditor. Our results extend to the context of inefficient bargaining considered by Bolton and Scharfstein. In fact, the two articles complement each other. We demonstrate why both short-term and long-term investors are desirable; whereas Bolton and Scharfstein analyze when it is optimal to have more than one short-term investor, and how liquidation rights should be allocated among them.

The remainder of the paper is organized as follows. Section II lays out the model. As a benchmark, Section III characterizes the optimal contract with one investor. Section IV develops the analysis of the two-investor case. Section V interprets the results, generates predictions on the relationship between investment profitability, debt maturity, and firm size, and relates these predictions to the empirical literature. Section VI concludes.

\section{THE MODEL}

Consider a risk-neutral firm that has a profitable long-term investment project, but not enough of its own funds to undertake it. The project extends over three idealized time-points, $t=0,1,2$. In $t=0$ the firm undertakes the investment, for which it has to raise the amount $I$ from outside. In $t=1$ the firm's activities have generated assets in place, $A_{1}$, and cash flow, $y_{1}$. Assets are measured in physical units whose outside valuation, i.e., their resale market price, is normalized to 1 . In $t=1$ all or parts of the assets can be

3. An interesting argument for the coexistence of debt and equity is that the existence of debt can change the structure of possible negotiations between managers/owners and third parties, such as suppliers or unions [Perotti and Spier 1993; Wells 1992]. While this argument is intriguing, it is difficult to imagine that, in general, strategic considerations with respect to third parties are the driving force behind the choice of capital structure.

4. In fact, to facilitate the comparison, our model formulation stays as close to the framework used by Bolton and Scharfstein [1992] as possible. 
either liquidated or left in place for further use by the firm. If the amount $L, 0 \leq L \leq A_{1}$, is liquidated, the assets that remain in the firm yield, in $t=2$, a cash flow of $y_{2}(L)$ and a total of $A_{2}(L)$ of assets in place. In $t=2$ all cash flows and assets are consumed.

To keep matters simple, we assume that first-period assets are certain. In other words, $A_{1}=\bar{A}$ with certainty, and this is common knowledge in $t=0$. Long-term assets and cash flows may be thought of as being uncertain (as of time $t=0$ and $t=1$ ), but since they enter all considerations only via their expected values, we can take them to be certain, as well. Hence, the functions $A_{2}(\cdot)$ and $y_{2}(\cdot)$ are deterministic and common knowledge in $t=0$. Uncertainty only prevails with respect to first-period cash flows $y_{1}$, a random variable whose distribution is given by

$$
y_{1}=\left\{\begin{array}{l}
0 \text { with probability } 1-\theta, \\
x \text { with probability } \theta .
\end{array}\right.
$$

Normalize the rate of interest to zero. We assume that the project is worth the investment, i.e., that $\theta x+A_{2}(0)+y_{2}(0)>I$, but that second-period assets $A_{2}(0)$ are not sufficient to cover the initial outlay: $A_{2}(0)<I$. Obviously, if it were possible to write binding, contingent contracts, the firm could easily attract one or more outside investors (their number would be irrelevant) who would be willing to put up $I$. However, in reality contracts are binding only insofar as either they are self-enforcing or their prescriptions are enforceable in court. The enforceability of repayment claims by outside investors in turn depends on how easily and to what extent courts can verify a firm's returns. Following Hart and Moore [1989], we make the following

ASSUMPTION 1. $y_{1}$ and $y_{2}$ accrue privately to the firm, and they are observable by investors, but not verifiable by courts. $A_{1}$ and $A_{2}$ are commonly observable and verifiable by courts.

For the sake of illustration we refer to the $y_{t}$ as "cash flows" and to the $A_{t}$ as "assets." These names reflect the observation that it is usually much easier for owners or management to divert liquid short-term funds for private use, perquisites, inefficient projects, etc. than to do so with long-lived, illiquid assets. In reality, of course, cash flows cannot be freely used by managers, and outsiders may sometimes find it difficult to get ahold of some of the assets when it comes to confiscation.

We will not distinguish between a firm and its owners or managers, but just assume that "the firm" values cash flows and assets. Given that $A_{2}(0)<I$ and the nonverifiability of cash flows, 
the firm therefore has to find a mechanism which persuades potential financiers that it will pay out future cash flows. Securing short-term claims with assets, together with the threat of their liquidation, can provide this mechanism here. To formalize this, we assume that the production function $y_{2}(L)+L$ is decreasing in $L$; i.e., a marginal unit of the assets yields more cash flow inside the firm than what this unit is worth outside. The manager strictly prefers to pay out liquid funds (if she has them), rather than repudiate and have the investors take away some of her assets in $t$ $=1$. In a narrow interpretation the assets thus earmarked for possible liquidation can be viewed as collateral. More generally, any contract that allows the investor to force asset sales or otherwise intervene in case of nonrepayment has the flavor associated here with "liquidation."

However, although both parties have an interest to agree to such a punishment ex ante, ex post liquidation will be inefficient. If $y_{1}=x$ and the firm defaults on its payments, both parties will be better off if they rescind the original contract and replace it by a new one with no liquidation and a cash payment by the firm, where the payment depends on expected future returns from the project and the bargaining situation after default. ${ }^{5}$ When signing the contract in $t=0$, the parties will anticipate a renegotiation following default in the good state rather than the mechanistic liquidation of assets. Hence, in order to evaluate what the investors can expect to receive in the good state, the parties have to forecast the outcome of a bargaining game.

We assume that a contract can specify an amount $L(\hat{R})$ which the investors are entitled to liquidate if the firm repays $\hat{R}$. Yet, actual liquidation and repayment following default, $(L, R)$, are determined through ex post bargaining. The investors' liquidation rights $L(\hat{R})$, however, determine the disagreement point in the bargaining. This assumption describes a basic feature of debtorcreditor negotiations, which take place in the shadow of bankruptcy and under the constant threat that creditors call their loans.

To simplify the analysis, we assume that bargaining takes the form of a take-it-or-leave-it payout offer by the firm. ${ }^{6}$ Investors can

5. The point here is that the old contract is indeed legally invalidated by the new one (which, in fact, is an important characteristic of bankruptcy law). Otherwise the fact that some repayment has occurred could be used to prove that the actual state has been good and hence the funds to repay the creditors are available.

6. This is as in Aghion and Bolton [1992] and Bolton and Scharfstein [1992] among others. It is not difficult to extend the analysis to more general bargaining 
accept this payment, in which case their old claims are invalidated, or reject the offer, in which case they can exercise their liquidation rights. As is standard, we assume that the investors accept a take-it-or-leave-it offer about which they are indifferent.

Summarizing the above description, this is the sequence of events in the model,

1. Parties write contract $C$; firm invests $I$.

2. First-period cash flow $y_{1}$ is realized.

3. Firm decides whether to default.

4. If firm defaults, renegotiation takes place.

5. $A_{2}$ and $y_{2}$ are realized. The end.

We shall ignore contracts that entail bargaining in $t=1$ and assume that the parties agree right away on liquidation and payout schemes $\left(L_{y 1}, R_{y 1}\right)$ that are renegotiation-proof. In the present context a scheme $\left(L_{y 1}, R_{y 1}\right)$ is renegotiation-proof if the firm, given $y_{1}$, does not want to enter into the bargaining, but rather delivers $\left(L_{y 1}, R_{y 1}\right)$. Since information at the bargaining stage is symmetric, and thus the outcome of the bargaining fully predictable, this assumption does not change the set of equilibrium outcomes.

Apart from providing for first-period transactions, the initial contract must also specify how second-period assets $A_{2}$ are divided between the parties in $t=2$. Because of the verifiability of $A_{2}$ it is irrelevant to whom $A_{2}$ accrues in the first place, only the division matters. We denote by $W$ the share going to the firm, and by $S^{i}$ the share of investor $i$. $W$ and $S^{i}$ depend on $(L, R)$.

We conclude the description of the model with a list of the technical assumptions, some of which have been introduced already.

ASSUMPTION 2.

(1) $A_{2}(\bar{A})=y_{2}(\bar{A})=0$

(2) $A_{2}(0)<I<A_{2}(0)+y_{2}(0)+\theta x$

(3) $x \geq y_{2}(0)$

(4) $y_{2}^{\prime} \leq-1$

(5) $-1<A_{2}^{\prime}<0$.

games, as long as the firm has some bargaining power and information about $y_{1}$ is symmetric (see Berglöf and von Thadden [1994]). As is well-known, the case of asymmetric information is more complex [Gale and Hellwig 1989]. For an analysis of the role of collateral in debt renegotiation under asymmetric information in a one-period framework, see Bester [1994]. 
Assumption 2(1) states that, if all the assets are liquidated in $t=1$, nothing is produced in $t=2$. This is a normalization to simplify notation. By 2(2) the project is worth the investment, but long-term assets alone are not sufficient to finance it. Assumption 2(3) simplifies the exposition by guaranteeing that in the good state the firm is not constrained by first-period cash flows. This assumption could be relaxed at the expense of a more complicated analysis with the same insights. ${ }^{7}$ Assumption 2(4) states that the firm prefers continuation to liquidation in $t=1$, because each additional unit of assets left inside the firm produces more than one unit of long-term cash flow. ${ }^{8}$ As opposed to that, by $2(5)$ long-term asset value increases less than on a one-to-one basis with short-term assets. This is the case, for example, if assets are interpreted as physical assets that are subject to depreciation: if $A_{2}(L)=\delta$ $(\bar{A}-L)$ with $\delta<1$, assets $L$ liquidated today are worth more to the investor than what he gets when he leaves the assets in the company. Similarly, 2(5) holds if the firm's management has some latitude to turn illiquid assets into nonverifiable cash flows in the time period from $t=1$ to $t=2$.

By Assumptions 2(4) and 2(5), using the assets in the firm is profitable in the long run, but at the margin the outside investors cannot capture enough of long-term returns to make continuation worthwhile for them alone; most of these returns stay within the firm. This creates an ex post conflict of interest between the firm and the outsiders that makes liquidation a credible threat.

\section{CONTRACTING WITH ONE INVESTOR}

As a benchmark, first consider the case where the firm contracts with only one (class of) investor(s) to finance the investment. In $t=0$ the two parties have to sign a contract $C=$ $\left(I+F, L(\cdot), R_{0}, R_{x}, W(\cdot)\right)$, where $R_{\xi}$ is repayment in state $y_{1}=\xi$ in $t=1, L(R)$ is the investor's liquidation right if payout in $t=1$ is $R$, $W(L, R)$ is the firm's share of second-period assets, and $I+F, F \geq 0$ is the amount of funds supplied by the investor in $t=0$. Note that if $F>0$, the firm has funds available in $t=1$ even if $y_{1}=0$. In this simple setting of two states of nature, we can view $R_{x}$ as the face value and $R_{0}$ as the default payment of debt.

7. See the discussion in footnote 11.

8. This assumption is a generalization of $(\star)$ in [Hart and Moore 1989] who assume that $y_{2}$ is linear with slope $\leq-1$. For the analysis of Sections III and IV to be valid, one only needs to assume that the firm is overall profitable in the long run i.e., that $y_{2}^{\prime}+A_{2}^{\prime}<-1$. However, Assumption 2(4) yields a simpler interpretation of the results obtained in Proposition 2. See footnote 18. 
Suppose that the firm, given $y_{1}=x$, decides to default in stage 3 , i.e., to make a repayment $\hat{R} \neq R_{x}$. By appropriately designing $L(\cdot)$, we can assume without loss of generality that $\hat{R}=R_{0}$. To simplify notation, let $L_{0} \equiv L\left(R_{0}\right)$, which is the value of the investor's collateral.

In the ensuing renegotiation the parties bargain over possible outcomes $(L, R, T) \in[0, \bar{A}] \times\left[0, x+F-R_{0}\right] \times \mathbb{R}$, where $L$ is liquidation, $R$ repayment, and $T$ a transfer from the investor to the firm in $t=2$, supplementing or undoing the contractual payment $W$. The disagreement outcome is $\left(L_{0}, 0,0\right)$, and the payoffs are

Firm: $\quad x+F-R_{0}-R+T+y_{2}(L)+W\left(L, R_{0}+R\right)$

Investor: $\quad R_{0}+R-T+L+A_{2}(L)-W\left(L, R_{0}+R\right)$.

By Assumption 2(3) and since $R_{0} \leq F$, the firm is not cash constrained. Since production is efficient (Assumption 2(4)-(5)), the Coase Theorem implies that $L=0$, regardless of $W(\cdot)$. Denote the total gain from avoiding liquidation by

$$
\Pi\left(L_{0}\right) \equiv y_{2}(0)-y_{2}\left(L_{0}\right)+A_{2}(0)-A_{2}\left(L_{0}\right)-L_{0} .
$$

The firm's take-it-or-leave-it offer holds the investor down to her liquidation value, and hence the bargaining yields the following payoffs:

$$
\begin{array}{ll}
\text { Firm: } & x+F-R_{0}+y_{2}\left(L_{0}\right)+W\left(L_{0}, R_{0}\right)+\Pi\left(L_{0}\right) \\
\text { Investor: } & R_{0}+L_{0}+A_{2}\left(L_{0}\right)-W\left(L_{0}, R_{0}\right) .
\end{array}
$$

Now consider the possibility that the firm "defaults" following $y_{1}=0$; i.e., that it repays $R_{x}$ instead of $R_{0}$. For this to occur, it would be necessary that $R_{x} \leq F$, which would imply that the investor does not break even on her investment $I+F$, a contradiction. Hence, if $y_{1}=0$, the firm repays $R_{0}$, and the investor liquidates $L_{0}$, which by Assumption 2(5) is ex post optimal for the investor.

To simplify notation, let $W_{0}=W\left(L_{0}, R_{0}\right)$ and $W_{x}=W\left(L_{x}, R_{x}\right)$ denote the firm's second-period compensation in the bad and the good state, respectively. As of time $t=0$ the principal data of the contracting problem now can be summarized as follows. The firm's expected profit from the venture is

$$
\begin{aligned}
P=(1-\theta)\left(F-R_{0}+y_{2}\left(L_{0}\right)+\right. & \left.W_{0}\right) \\
& +\theta\left(x+F-R_{x}+y_{2}\left(L_{x}\right)+W_{x}\right) .
\end{aligned}
$$


The investor provides $I+F$ if she expects to at least break even on the investment; i.e., if

$$
\begin{aligned}
(1-\theta)\left(R_{0}+L_{0}+A_{2}(\right. & \left.\left.L_{0}\right)-W_{0}\right) \\
& +\theta\left(R_{x}+L_{x}+A_{2}\left(L_{x}\right)-W_{x}\right) \geq I+F .
\end{aligned}
$$

The firm does not default in the good state in stage 3 if sticking to the contract yields at least as much as the outcome of the bargaining; i.e., if

(4) $x+F-R_{x}+y_{2}\left(L_{x}\right)+W_{x} \geq x+F-R_{0}+y_{2}\left(L_{0}\right)+W_{0}+\Pi\left(L_{0}\right)$.

We will refer to (4) as the renegotiation-proofness constraint. 9 In the remainder of this section we characterize the optimal contract. We start with some simple observations.

LEMMA 1. In an optimal contract, $L_{0}>0, R_{x}-R_{0}-W_{x}<x$, and $L_{x}=0$. Furthermore, the participation constraint (3) and the renegotiation-proofness constraint (4) bind.

Proof. Suppose that $L_{0}=0$. Then the renegotiation-proofness constraint (4) reduces to $R_{x}-R_{0} \leq y_{2}\left(L_{x}\right)-y_{2}(0)+W_{x}-W_{0}$. This implies for the expected return to the investor that

$$
\begin{aligned}
(1-\theta)\left(R_{0}+A_{2}(0)-W_{0}\right)+\theta\left(R_{x}\right. & \left.+L_{x}+A_{2}\left(L_{x}\right)-W_{x}\right) \\
& <R_{0}+A_{2}(0)-W_{0}<I+F
\end{aligned}
$$

by Assumption 2(2). Hence without the threat of liquidation, the investor cannot extract enough funds from the firm to cover her initial investment. Next, since $\Pi\left(L_{0}\right)>0$, the renegotiationproofness constraint implies that

$$
R_{x}-R_{0}-W_{x} \leq y_{2}\left(L_{x}\right)-y_{2}\left(L_{0}\right)-\Pi\left(L_{0}\right)-W_{0}<y_{2}(0) \leq x,
$$

by Assumption 2(3). Next, suppose that $L_{x}>0$. To see that this is not optimal, reduce $L_{x}$ marginally by $\Delta>0$ and increase $R_{x}-R_{0}-$ $W_{x}$ by $\left(1+A_{2}^{\prime}\left(L_{x}\right)\right) \Delta$. This change leaves the investor's return (to the first order) unchanged. Furthermore, $y_{2}\left(L_{x}\right)-R_{x}+R_{0}+W_{x}$ increases marginally by $-\left(A_{2}^{\prime}\left(L_{x}\right)+y_{2}^{\prime}\left(L_{x}\right)+1\right) \Delta>0$, hence (4) continues to hold, and $P$ increases.

Finally, suppose that (4) does not bind. Consider the following variation: reduce $L_{0}$ by a marginal $\Delta>0$, and increase $R_{x}-R_{0}-$ $W_{x}$ by $(1-\theta) / \theta\left(1+A_{2}^{\prime}\left(L_{0}\right)\right) \Delta$. For small $\Delta$ this does not affect (4)

9. See Rubinstein and Wolinsky [1992] for a detailed discussion of the concept of renegotiation-proofness in the context of incomplete contracts. 
and leaves the investor (to the first order) indifferent. $P$, however, increases by $-(1-\theta)\left(y_{2}^{\prime}\left(L_{0}\right)+A_{2}^{\prime}\left(L_{0}\right)+1\right) \Delta>0$.

QED

Lemma 1 simplifies the contracting problem considerably. Its main assertion is that $R_{x}-W_{x}<x+R_{0}$ : the firm does not need all short-term cash flows to meet its obligations in the first period. This is important because, as the other observations show, the parties have an incentive to trade off liquidation against cash flows - an increase in $R_{x}-R_{0}-W_{x}$ compensated by a decrease in liquidation rights is Pareto-improving. A priori, this trade-off is limited by ex post opportunism (the renegotiation-proofness constraint) and available cash flows. Assumption 2(3), on which Lemma 1 rests, assumes away this second limitation. As mentioned in Section II, Assumption 2(3) could be relaxed without invalidating Lemma $1 .^{10}$

To solve the contracting problem, now insert the participation constraint (3) into the firm's objective function to obtain

$$
P=(1-\theta)\left(y_{2}\left(L_{0}\right)+A_{2}\left(L_{0}\right)+L_{0}\right)+\theta\left(x+y_{2}(0)+A_{2}(0)\right)-I \text {. }
$$

Hence, the transfers $W_{0}$ and $W_{x}$, which cancel out, influence $P$ at most indirectly, via the renegotiation-proofness constraint. Similarly, $F$ and $R_{0}$ have no influence on the consolidated profit function. Equation (5) shows that the only costs the firm must bear apart from $I$ are those of liquidation, which arise from the need to punish its anticipated opportunism. Since liquidation is inefficient, $P$ is maximized if $L_{0}$ is minimized. The consolidated optimization program therefore is

$$
\min _{\left(L_{0}, W_{0}, F-R_{0}\right)} L_{0}
$$

$\left(P_{1}\right) \quad$ subject to $0 \leq L_{0} \leq \bar{A}, \quad W_{0} \geq 0, \quad F-R_{0} \geq 0$

$$
L_{0}+A_{2}\left(L_{0}\right)=I+W_{0}+F-R_{0} \text {. }
$$

Here, (6) is obtained by inserting the renegotiation-proofness constraint (4) into the participation constraint (3) and using

10. All one has to guarantee is that for the optimal $L_{0}, x>y_{2}(0)-y_{2}\left(L_{0}\right)-$ $\Pi\left(L_{0}\right)$. However, phrasing this in terms of the initial data of the problem is painful. Yet, even if there were no assumption of this type, i.e., if first-period cash flows in the good state were small as compared with second-period cash flows, the qualitative features of the analysis would remain unchanged. In this case, first-period cash flows would have to be paid out completely, there would be partial liquidation in the good state, the renegotiation-proofness constraint would not bind, and the analysis would become slightly more complicated. Assumption 2(3) allows us to make the argument as simply as possible. 
Lemma 1. This formulation shows that the firm's compensation in the good state is irrelevant for the solution of the contracting problem. As long as feasibility, participation, and renegotiationproofness constraints are satisfied, the parties may set $W_{x}$ at any level they like. The reason for this indifference is simple: since $W_{x}$ must de facto be paid out of the funds extracted from management in $t=1$, it cannot be effectively used to induce management to pay out (things would be different if some effort had to be elicited from the management after $t=1$ as in Dewatripont and Tirole [1994]). But for the same reason-the parties only consider net payout $R_{x}-W_{x}$-a positive $W_{x}$ is not distorting, either.

Hence, the parties are effectively concerned with setting an optimal liquidation level $L_{0}$, with $R_{x}$ determined by renegotiationproofness and $W_{0}$ and $F-R_{0}$ entering as adjustments to the investor's participation constraint.

Proposition 1. Problem $\left(\boldsymbol{P}_{1}\right)$ has a solution iff

$$
\bar{A} \geq I \text {. }
$$

This solution is unique and has $W_{0}=F-R_{0}=0$.

Proof. The left-hand side of (6) is strictly increasing in $L_{0}$ by Assumption 2(5). If (6) has a solution, it is unique and increasing in $W_{0}+F-R_{0}$. Hence, optimally $W_{0}=F-R_{0}=0$.

QED

As was to be expected, in the optimal contract $W_{0}=0$. This is because compensation in the bad state is basically a transfer à fond perdu, which additionally sets the wrong incentives by rewarding the firm for not paying out, and hence is viewed as an additional cost of capital. Furthermore, up-front transfers $F$ can be included in the contract, but they are irrelevant, and they must be fully neutralized; i.e., the payout in each state must increase by $F$. Because liquidation rights can contractually be made contingent on repayments, up-front payments do not affect the basic trade-off between inefficient liquidation in bad cash flow states and leverage to pay out in good cash flow states. If, for example, a contract specifies a high $L_{0}$ to force the firm to pay out when $y_{1}=x$, this amount will be liquidated in $y_{1}=0$, regardless of the up-front transfer to the firm in the initial period. Therefore, the parties may as well set $F=0 .{ }^{11}$

11. It is instructive to compare this setting with the corresponding model in Hart and Moore [1989, Proposition 3]. There, contracts only specify face levels of 
Proposition 1 shows that if $A_{2}(0)<I \leq \bar{A}$ the problem of insufficient long-term assets is overcome by pledging short-term assets to make up for the deficiency. Since the firm is cashconstrained in state $y_{1}=0$, the investor indeed liquidates the amount $L_{0}$ in the low cash-flow state. If the firm has sufficient funds, it prefers to repay the investor to avoid liquidation of $L_{0}$. But since the investor would stand to lose the amount $A_{2}(0)-A_{2}\left(L_{0}\right)$ of future returns from liquidating, the firm's repayment is correspondingly lower, namely, $R_{x}=L_{0}-\left[A_{2}(0)-A_{2}\left(L_{0}\right)\right]$.

If $A_{2}(0)<I \leq \bar{A}$, the assets in period 1 are more valuable than the original investment (the firm creates value added). If $\bar{A}<I$, the context is one in which the original investment depreciates. By (7), such an investment cannot be financed by a single investor.

\section{CONTRACTING WITH Two INVESTORS}

Suppose that the firm considers having its project financed by two (classes of) outside investors. The financial contract now must allocate payout and liquidation rights to these two outsiders. As in the last section, liquidation rights cannot be made contingent on the state of nature $y_{1}$, but only on payouts.

To keep the analysis simple, we assume that investor $i$ 's liquidation rights only depend on the payout made to her. In particular, if the firm defaults on both investors, repaying only $R^{1}$ and $R^{2}$, respectively, instead of the contractual payment, investor $i$ 's liquidation right is $L^{i}\left(R^{i}\right)$, independent of $R^{j}, j \neq i$. In a strict interpretation, this contractual setting corresponds to the case of secured debt in the framework of debt collection law: each investor has a lien on some portion of the firm's assets and is allowed to foreclose her security interests if the debtor defaults on the obligation to her. In practice, bankruptcy law, as opposed to debt collection law, implies that one investor's liquidation rights sometimes depend on more complex considerations. ${ }^{12}$ However, for the present simple analysis the above assumption is no restriction.

short-term debt, which the creditor can unilaterally reduce after observation of $y_{1}$, together with unconditional liquidation rights. Hart and Moore show that the optimal contract typically involves a positive up-front transfer, because this credibly reduces the creditor's incentives to liquidate in low cash flow states. Given that she cannot commit to low liquidation levels, it is strictly optimal to use this instrument.

12. If we restrict attention to secured claims, both debt collection and bankruptcy law in most countries share the feature that is fundamental to our analysis: if the debtor does not repay the creditor, the creditor is entitled to assets, liquidation proceeds, or other payments from the debtor, at least up to the amount of collateralization. In the United States this holds for all the relevant chapters of the Bankruptcy Code $(7,11,13)$. 
As discussed in the last section, we can assume that the investors provide exactly $I$ in $t=0$. Unlike the one-investor case, the parties here also must determine how to split second-period assets, conditional on first-period events. Hence, the initial contract must specify the following variables:

$I^{i}$ : contribution of investor $i$,

$R_{y_{1}}^{i}$ : repayment obligation to $i$ in state $y_{1}$ in $t=1$,

$L^{i}(\cdot)$ : amount of assets $i$ can liquidate if she receives $R^{i}$ in $t=1$,

$S^{i}(\cdot)$ : investor $i$ 's share of assets in $t=2$ if first-period liquidation is $\left(L^{1}, L^{2}\right)$,

for $i=1,2 .{ }^{13}$ The $S^{i}$ have to satisfy the feasibility condition,

$$
S^{1}\left(L^{1}, L^{2}\right)+S^{2}\left(L^{1}, L^{2}\right)=A_{2}\left(L^{1}+L^{2}\right) \quad \text { for all } L^{1}, L^{2} .
$$

Let us now consider in more detail the default and renegotiation game that the firm can trigger in $t=1$. Suppose that the firm defaults, against one or both of the investors, following the cash flow realization $y_{1}$. In principle, this can have two consequences. Either, all three parties come together to renegotiate ("bankruptcy"), or only one investor negotiates with the firm ("debt collection"). This latter constellation occurs if and only if one investor prefers to negotiate, the other investor prefers to stay out of the renegotiation, and the investor who stays out of the renegotiation does not liquidate assets if the firm is not cashconstrained. If a contract were structured such that this last condition were not met, given the overall optimality of keeping the assets in place, the parties would get together ex post to upset the contract. We describe both cases in turn. ${ }^{14}$

To begin with, note that in state $y_{1}=0$ we necessarily have $R^{1}=R_{0}^{1}=R^{2}=R_{0}^{2}=0$ and liquidation of $L_{0}^{1}, L_{0}^{2}$ (remember that by

13. As in the last section, it is straightforward to see that the firm's share $W$ of second-period assets should be zero. Hence, we ignore this variable here. Also it is clear that conditioning second-period results only on $L^{1}, L^{2}$, and not on $L^{1}, L^{2}, R^{1}, R^{2}$ is no loss of generality.

14. In this paper we do not attempt to answer the question whether the default and renegotiation procedures of stages 3-4 are optimal from an ex ante bankruptcy design perspective (see Harris and Raviv [1991] and Aghion, Hart, and Moore [1992] for recent work on this problem). We simply intend to capture some basic features of existing debtor-creditor law. An interesting modification of the present structureintroducing a feature of debt collection law-is to drop the assumption of unanimity in the trilateral bargaining game described below. This modification would not change the main arguments, but would entail an analysis of the second derivatives of long-term returns, as in Bolton and Scharfstein [1992]. 
Assumption 2(5) liquidation is ex post optimal from the point of view of the investors). The interesting case is default in the good state ("strategic default").

Suppose that the firm defaults, and both investors negotiate with the firm. As in Section III, we can assume that $R^{1}=R^{2}=0$, and to simplify notation we again denote by $L_{0}^{l} \equiv L^{l}(0), i=1,2$, the value of $i$ 's liquidation rights.

In three-party bargaining, the firm has some opportunity to force the investors into mutual concessions. To capture this, we assume that if one participant rejects an offer, negotiations break down and both investors proceed to liquidate. Hence, the firm only has to offer each investor her reservation value resulting from total liquidation. Since liquidation is inefficient (Assumption 2(4)), the firm's take-it-or-leave-it offer is a triple $\left(R^{1}, R^{2}, T\right)$, where $T$ is a possible transfer from investor 2 to investor 1 . Keeping the investors indifferent between liquidating and accepting the offer requires setting

$$
\begin{aligned}
& R^{1}+T+S^{1}(0,0)=L_{0}^{1}+S^{1}\left(L_{0}^{1}, L_{0}^{2}\right) \\
& R^{2}-T+S^{2}(0,0)=L_{0}^{2}+S^{2}\left(L_{0}^{1}, L_{0}^{2}\right)
\end{aligned}
$$

By adding up (9) and using (8), the payoffs resulting from three-party bargaining then are

$$
\begin{array}{ll}
\text { Firm: } \quad x+y_{2}\left(L_{0}\right)+\Pi\left(L_{0}\right) \\
\text { Investor 1: } \quad L_{0}^{1}+S^{1}\left(L_{0}^{1}, L_{0}^{2}\right) \\
\text { Investor 2: } \quad L_{0}^{2}+S^{2}\left(L_{0}^{1}, L_{0}^{2}\right),
\end{array}
$$

where $\Pi\left(L_{0}\right)$, again, is the social surplus from renegotiation as defined in (1), and $L_{0}=L_{0}^{1}+L_{0}^{2}$ denotes total potential liquidation (total collateral). Note that in (10) the transfer $T$ cancels out. Regardless of the distribution of liquidation rights, the firm can secure the same renegotiation rent as in the one-investor case, (2).

Now suppose that following default only one investor, say investor 1 , negotiates with the firm. The resulting bargaining game $\Gamma\left(L_{0}^{1}, x-R^{2}\right)$ between investor 1 and the firm is as in Section III. The cash flow to be bargained over is either $x-R_{x}^{2}$ (in case of partial default) or $x$ (in case of total default). The firm and the investor bargain over possible outcomes $(L, R)$, where $L$ is liquidation and $R$ is payout by the firm. The disagreement outcome is 
$\left(L_{0}^{1}, 0\right)$, and payoffs are

$$
\text { Firm: } \quad x-R^{2}-R+y_{2}(L)
$$

Investor 1: $R+L+S^{1}(L, 0)$.

The firm's take-it-or-leave-it offer maximizes its own payoff subject to the constraint that the investor gets at least $L_{0}^{1}+S^{1}$ $\left(L_{0}^{1}, 0\right)$. Clearly, this constraint binds. Hence,

$$
R=S^{1}\left(L_{0}^{1}, 0\right)-S^{1}(L, 0)+L_{0}^{1}-L .
$$

By designing the $S^{1}(L, 0)$ appropriately, we can restrict attention to $L \in\left\{0, L_{0}^{1}\right\}$. Since the firm cannot be forced to get less than its liquidation payoff in the bargaining, any outcome must satisfy

$$
x-R^{2}-R+y_{2}(L) \geq x-R^{2}+y_{2}\left(L_{0}^{1}\right) .
$$

Consolidating (11) and (12) shows that the bargaining will result in $L=0$ if

$$
S^{1}(0,0)-S^{1}\left(L_{0}^{1}, 0\right)-L_{0}^{1}+y_{2}(0)-y_{2}\left(L_{0}^{1}\right) \geq 0,
$$

and in $L=L_{0}^{1}$ otherwise. Condition (13) states that the bilateral surplus from avoiding liquidation is positive: it is a condition on the contractually determined future returns to investor 1 . If (13) is violated, the contract is structured such that firm and investor 1 find it in their joint interest to liquidate. Given the overall profitability of continuing without liquidation, this must come at the expense of the second investor who will therefore not stay out of the negotiations. When considering the case of bilateral bargaining, it is therefore necessary to restrict attention to contracts satisfying (13). Default and bilateral renegotiation then result in the following payoffs:

Firm: $\quad x-R^{2}+y_{2}\left(L_{0}^{1}\right)+\Pi_{1}\left(L_{0}^{1}\right)$

Investor 1: $\quad L_{0}^{1}+S^{1}\left(L_{0}^{1}, 0\right)$

Investor 2: $R^{2}+S^{2}(0,0)$,

where the bilateral renegotiation rent $\Pi_{1}$ is

$$
\begin{aligned}
\Pi_{1}\left(L_{0}^{1}\right) & =y_{2}(0)-y_{2}\left(L_{0}^{1}\right)+S^{1}(0,0)-S^{1}\left(L_{0}^{1}, 0\right)-L_{0}^{1} \\
& =\Pi\left(L_{0}^{1}\right)+S^{2}\left(L_{0}^{1}, 0\right)-S^{2}(0,0) .
\end{aligned}
$$


By (14) and (15) the firm's payoff from renegotiation with investor 1 , for a given value of $L_{0}^{1}$, is smaller than in the one-investor case if $S^{2}\left(L_{0}^{1}, 0\right)<S^{2}(0,0)$. Since by renegotiationproofness in the good state the firm will pay out more the less it stands to gain from default, optimal contracts minimize the firm's renegotiation payoff. The following lemma characterizes contracts that minimize this payoff.

LEMMA 2. Suppose that aggregate liquidation rights $L_{0}$ are fixed. Any contract that minimizes the firm's payoff from bilateral bargaining with investor 1 has $L_{0}^{2}=0$. Furthermore,

$$
\text { if } \Pi\left(L_{0}\right) \leq A_{2}(0) \text {, it has } S^{2}(0,0)-S^{2}\left(L_{0}^{1}, 0\right)=\Pi\left(L_{0}\right) \text {; }
$$

$$
\text { and if } \Pi\left(L_{0}\right)>A_{2}(0) \text {, then } S^{2}(0,0)=A_{2}(0), S^{2}\left(L_{0}^{1}, 0\right)=0 \text {. }
$$

Proof. From (13), (14), and (15), minimizing the renegotiation payoff is equivalent to finding nonnegative numbers $L_{0}^{1}, y \equiv$ $S^{2}\left(L_{0}^{1}, 0\right)$, and $z \equiv S^{2}(0,0)$,

$$
\begin{aligned}
& 0 \leq L_{0}^{1} \leq L_{0}, \\
& 0 \leq y \leq A_{2}\left(L_{0}^{1}\right), \\
& 0 \leq z \leq A_{2}(0), \\
& z-y \leq \Pi\left(L_{0}^{1}\right),
\end{aligned}
$$

which minimize

$$
y-z-\left(A_{2}\left(L_{0}^{1}\right)+L_{0}^{1}\right) .
$$

Increasing $L_{0}^{1}$ does not change the admissibility conditions (18) for $y$ and $z$, hence, by Assumption 2(5), $L_{0}^{1}=L_{0}$. Depending on which inequality in (18) binds, we then get either (16) or (17).

QED

Lemma 2 shows the principal effect at work if default leads to bilateral bargaining. The contract should display a maximum degree of asymmetry in the temporal structure of return claims. This is achieved by two distinct features. First, asymmetry between investors should be maximal, in the sense that all short-term liquidation rights should lie with one investor $\left(L_{0}^{2}=0\right.$ in the case considered in Lemma 2). In this case, we shall call investor 2 the long-term investor, and investor 1 the short-term investor.

Second, the asymmetry between the short-term investor's long-term returns in the different states should be maximal. To 
make this clear, denote the minimal feasible difference between the long-term investor's long-term returns $(z-y$ in the proof of Lemma 2) by

$$
\Delta\left(L_{0}\right) \equiv S^{2}(0,0)-S^{2}\left(L_{0}, 0\right)= \begin{cases}\Pi\left(L_{0}\right) & \text { if } \Pi\left(L_{0}\right) \leq A_{2}(0) \\ A_{2}(0) & \text { if } \Pi\left(L_{0}\right) \geq A_{2}(0)\end{cases}
$$

When the short-term investor bargains with the firm in strategic default, he should not only have maximal leverage $\left(L_{0}^{1}=L_{0}\right)$, but also his incentive to drive the firm into liquidation should be maximal. For this, his long-term returns after liquidation, $S^{1}\left(L_{0}^{1}, 0\right)$, should be as large, and those after repayment, $S^{1}(0,0)$, as small as possible, which is achieved by setting $S^{1}\left(L_{0}^{1}, 0\right)-S^{1}(0,0)=$ $A_{2}\left(L_{0}^{1}\right)-A_{2}(0)+\Delta\left(L_{0}^{1}\right)$.

Lemma 2 shows that, depending on the aggregate level of liquidation, $L_{0}$, this second asymmetry can be strong enough to completely eliminate all gains from renegotiation; i.e., achieve $\Pi_{1}\left(L_{0}\right)=0$ (if (16) holds), but need not (if (17) holds). Certainly, however, the firm's renegotiation payoff from bilateral bargaining can be made smaller than that from trilateral bargaining. Hence, ex ante a contract with maximal asymmetry between investors is in all parties' interest. ${ }^{15}$

To see whether this arrangement is also upheld ex post, note that the long-term investor's payoff from not joining the renegotiation is $S^{2}(0,0)$, while that from joining is $S^{2}\left(L_{0}, 0\right)=S^{2}(0,0)-\Delta\left(L_{0}\right)$. In fact, the long-term investor would stand to lose from trilateral bargaining to the benefit of the firm. However, staying out of the renegotiation (e.g., by making herself unavailable) hurts neither herself nor the short-term investor, because her refusal does not trigger liquidation, and the short-term investor's interest to negotiate ensures efficient continuation. ${ }^{16}$

The complete determination of the optimal contract is now straightforward. Since the long-term investor has no short-term liquidation rights, her short-term claims must be zero, too. The

15. Note that this is true as long as the firm captures a positive part of the total surplus from renegotiation (and not only if it captures the whole surplus, as assumed here).

16. This mechanism does not work if there is only one investor. If a single investor does not want to renegotiate following default, this ultimately triggers liquidation. Anticipating this, she renegotiates. Liquidation can be threatened credibly if an investor is objectively unable to renegotiate; e.g., because "the investor" is actually a whole class of widely dispersed claim-holders with no provisions to overcome the free-rider problem [Grossman and Hart 1980]. It is well-known that such a structure has desirable commitment properties. Our analysis is concerned with situations without such commitment mechanisms. 
equilibrium payout $R_{x}^{1}$ in the good state then satisfies the following renegotiation-proofness constraint:

$$
x-R_{x}^{1}+y_{2}(0) \geq x+y_{2}\left(L_{0}\right)+\Pi_{1}\left(L_{0}\right),
$$

where, as in Lemma $1, L_{x}=0$ (no liquidation if there is payout). Again from Lemma 1, the renegotiation-proofness constraint binds, yielding

$$
R_{x}^{1}=y_{2}(0)-y_{2}\left(L_{0}\right)-\left(\Pi\left(L_{0}\right)-\Delta\left(L_{0}\right)\right) .
$$

The ex ante expected returns to the two investors from this contract are, respectively,

$$
\begin{aligned}
& (1-\theta)\left(L_{0}+S^{1}\left(L_{0}, 0\right)\right)+\theta\left(R_{x}^{1}+S^{1}(0,0)\right), \\
& (1-\theta) S^{2}\left(L_{0}, 0\right)+\theta S^{2}(0,0),
\end{aligned}
$$

which can be consolidated, using (20), to give total expected return to investors as

$$
E\left(L_{0}\right) \equiv L_{0}+A_{2}\left(L_{0}\right)+\theta \Delta\left(L_{0}\right) .
$$

Since investors are assumed to make zero expected profits, the optimal amount of liquidation rights in the two-investor case is now given by

$$
E\left(L_{0}^{\star}\right)=I \text {. }
$$

In order to solve (21) and to compare it with the corresponding one-investor condition (5), note that $\Pi\left(L_{0}\right)$ is strictly increasing in $L_{0}$ : the higher the liquidation right, the higher the gain from avoiding liquidation. This implies that there is at most one solution $0 \leq \bar{L} \leq \bar{A}$ to the equation $\Pi(\bar{L})=A_{2}(0)$. By Assumption 2(4), there is exactly one such solution. Hence,

$$
\Delta\left(L_{0}\right)= \begin{cases}\Pi\left(L_{0}\right) & \text { if } L_{0} \leq \bar{L} \\ A_{2}(0) & \text { if } L_{0}>\bar{L}\end{cases}
$$

It follows that $E(\cdot)$ is continuous (though not differentiable) and strictly increasing for $0 \leq L_{0} \leq \bar{A}$, and the solution to (21) is unique.

Depending on $I$, the short-term repayment is now determined by (20), the long-term claims by (16), (17), and (8). Lemma 2 indicates that we can distinguish two cases, which we formulate as Propositions 2 and 3. 
Proposition 2. Suppose that

$$
\bar{L}+A_{2}(\bar{L})+\theta A_{2}(0) \geq I .
$$

Then for any $D \in\left[0, A_{2}(0)-\Pi\left(L_{0}^{\star}\right)\right]$, the following capital structure is optimal:

(WS)

$$
\begin{array}{ll}
L_{0}^{1}=L_{0}^{\star}, & L_{0}^{2}=0, \\
R_{x}^{1}=y_{2}(0)-y_{2}\left(L_{0}^{\star}\right), & R_{x}^{2}=0, \\
S^{1}(0,0)=D, & S^{2}(0,0)=A_{2}(0)-D, \\
S^{1}\left(L_{0}^{\star}, 0\right)=y_{2}(0)-y_{2}\left(L_{0}^{\star}\right)-L_{0}^{\star}+D, & S^{2}\left(L_{0}^{\star}, 0\right)=A_{2}(0)-\Pi\left(L_{0}^{\star}\right)-D,
\end{array}
$$

where $L_{0}^{\star}$ is given by (21). Along the equilibrium path, these are the only optimal capital structures.

Note that uniqueness only holds along the equilibrium path; off the equilibrium-i.e., if $\left(L^{1}, R^{1}\right) \neq\left(L_{0}^{1}, 0\right),\left(0, R_{x}^{1}\right)$-the schedules $L(\cdot), S^{1}(\cdot), S^{2}(\cdot)$ are not unique.

Before discussing Proposition 2, we first continue the characterization of optimal capital structure. Two observations, however, are worth being pointed out immediately. First, if condition (22) holds, the optimal capital structure has one degree of freedom. It only exhibits a weak separation of claims over time: while investor 2 only holds long-term claims, the short-term investor can also hold fixed claims $D$ on long-term returns in both states. Second, since the firm's renegotiation rent is eliminated, the structure (WS) is second-best optimal: if an investor could commit to liquidating an amount $L_{0}$, she could not do better than (WS). Both these features vanish if $(22)$ ceases to hold.

Proposition 3. Suppose that

$$
\bar{L}+A_{2}(\bar{L})+\theta A_{2}(0)<I \leq \bar{A}+\theta A_{2}(0) .
$$

Then the following capital structure is the unique optimum to the contracting problem:

$$
\begin{array}{ll}
L_{0}^{1}=L_{0}^{\star}, & L_{0}^{2}=0, \\
R_{x}^{1}=A_{2}\left(L_{0}^{\star}\right)+L_{0}^{\star}, & R_{x}^{2}=0, \\
S^{1}(0,0)=0, & S^{2}(0,0)=A_{2}(0), \\
S^{1}\left(L_{0}^{\star}, 0\right)=A_{2}\left(L_{0}^{\star}\right), & S^{2}\left(L_{0}^{\star}, 0\right)=0 .
\end{array}
$$


In (SS), separation of claims is strict: the short-term investor has no claims on long-term assets in the good state. As in Proposition 2, uniqueness clearly only holds along the equilibrium path. Note that by Assumption 2(5), the right-hand side of (23) is indeed not smaller than the left-hand side. Finally, note that if both (22) and (23) are violated, the project cannot be financed even by including two investors. ${ }^{17}$

The main characteristic of the contracts derived in Propositions 2 and 3 is that they drive a wedge between short-term and long-term investor interests. This creates an externality on the side of the short-term investor that reduces the firm's rents from bargaining if it attempts to renege on the contract ex post. As pointed out earlier, this externality indeed persists ex post, because it is not in the long-term investor's interest to join the renegotiation and because the short-term investor's presence ensures efficient continuation.

To conclude the analysis, we briefly show that the optimal contract is also stable against collusion among two of the three parties involved. Consider first the scope for ex post sidecontracting between the two investors. Since the value of the long-term investor's claims is affected by liquidation, is she willing to pay the short-term investor for not liquidating $L_{0}$ in $t=1$ ? Such cooperation is not profitable for the very reason that the single investor in the one-investor case has an ex post incentive to liquidate: because $A_{2}^{\prime}>-1$ (Assumption 2(5)), paying the shortterm investor to reduce liquidation would cost the long-term investor more than she would gain from the increase in the value of long-term assets.

Judging from the legal and the earlier economics literature, the coalition involving the firm and the short-term investor is potentially the most serious problem in practice. The standard argument here is that the two parties could use the opportunity of bilateral bankruptcy negotiations to hurt the long-term investor through excessive liquidation. But, again, in the present context there is no such incentive. Not only does the firm care more about marginal long-term returns than the outsiders $\left(A_{2}^{\prime}>y_{2}^{\prime}\right.$ by Assump-

17. The whole analysis remains valid if one relaxes Assumption 2(4) to $y_{2}^{\prime}+$ $A_{2}^{\prime}<-1$. Now, for $S^{1}\left(L_{0}^{\star}, 0\right)$ to be nonnegative, the restriction on $D$ in Proposition 2 must be strengthened to $\max \left\{0, L_{0}^{\star}+y_{2}\left(L_{0}^{\star}\right)-y_{2}(0)\right\} \leq D \leq A_{2}(0)-\Pi\left(L_{0}^{\star}\right)$. Hence, if $L_{0}^{\star}+y_{2}\left(L_{0}^{\star}\right)>y_{2}(0)$ not enough short-term cash flow can be extracted from the firm, and the short-term investor takes a long-term stake to compensate for this shortfall. 
tions 2(4), (5), but, since $y_{2}^{\prime}<-1$, liquidation is outright inefficient from the firm's perspective. Hence, if the short-term investor wanted to bribe the firm in the good state to fake bankruptcy, he would have to put up more in cash than he would receive in asset value.

\section{Investment Size, Debt Maturity, and Collateralization}

In this section we review some features of the optimal contract identified in the last section in less technical terms and provide some results on comparative statics. We start by analyzing how the optimal capital structure depends on the relative size of the investment, $I$. Variations in $I$, with all other project characteristics held fixed, change the project's profitability, and are therefore similar to, e.g., changes in the project's long-term returns $y_{2}$ or $A_{2}$. Using Propositions 2 and 3 , we can distinguish three different regions of $I$, ceteris paribus.

If $I \leq A_{2}(0)$, i.e., if investment is small relative to the verifiable long-term returns it generates, then all repayments can be made out of $A_{2}$, there is no short-term debt, and hence no short-term default. The firm only issues safe long-term claims with face value $D=I$.

If $I$ increases beyond $A_{2}(0)$, claims on short-term returns must be issued to make the project viable. In the range $A_{2}(0)<I \leq \bar{L}+$ $A_{2}(\bar{L})+\theta A_{2}(0)$, the optimal capital structure has one investor holding short-term debt with face value $R_{x}^{1}$ and partially backed by liquidation rights $L_{0}^{1}$. Although default is possible (and happens with probability $1-\theta$ ), short-term debt $I^{s}=I^{1}-D$ is riskless, because the amount outstanding after default, $R_{x}^{1}-L_{0}^{1}$, is essentially rescheduled and repaid in $t=2$. The other investor contributes $I^{e}=\theta \Delta\left(L_{0}^{\star}\right)$ and holds a state-contingent long-term claim. Finally, the optimal security issue includes safe long-term claims of face value $I^{l} \equiv A_{2}(0)-\Pi\left(L_{0}^{\star}\right)$, held by any or both of the investors.

Note that the fixed long-term claims serve no strategic purpose. In the derivation of the optimal contract, they arise as a residual: even without them, the short-term investor has maximum leverage over the firm, and the other investor is sufficient to absorb the balance. Hence, a contract in which these claims are held by a third investor does as well as one where they are held by one or both of the two investors.

If the investment requires more than $\bar{L}+A_{2}(\bar{L})+\theta A_{2}(0)$, fixed long-term claims are no longer optimal. In the parameter region 
given in Proposition 3, the only long-term claim issued by the firm is state-contingent, paying $A_{2}(0)$ in the good and 0 in the bad state.

An increase of $I$ beyond $\bar{A}+\theta A_{2}(0)$, the project's "finance capacity," makes it impossible to finance the project. Yet, the project's finance capacity is larger than its first-period asset liquidation-value $\bar{A}$, which is what can be raised by finance through a single investor (see Proposition 1). For example, if first-period assets are assumed to be just the initial investment reduced by depreciation, one has $\bar{A}<I$, and exclusive finance is not viable at all. However, so long as the assets do not depreciate too fast ( $I \leq \bar{A}+\theta A_{2}(0)$ ), the project can be financed by two investors. The difference between the finance capacities with one and two investors indicates how much more of its expected future returns the firm can credibly commit to pay out in a two-investor arrangement.

The claims identified above resemble the standard financial instruments of short-term debt, senior long-term debt, and equity (or junior long-term debt). One difference, however, which arises from the simplifying structure of the model, should be noted immediately. In the present model, all uncertainty is resolved at time $t=1$, and therefore, the contingency of second-period returns refers to first-period events. To obtain a fuller analogy to observed financial instruments, the model would have to be generalized to allow for second-period uncertainty as well.

The following proposition summarizes the above discussion. Moreover, it describes how two indicators of the relative importance of short-term debt depend on 1 , the share of short-term debt in the overall issue and the ratio of short-term debt to equity.

PROPOSITION 4. The optimal capital structure can consist of three types of claims: fixed long-term claims, state-contingent longterm claims, and collateralized short-term claims. If $I \leq A_{2}(0)$, only fixed long-term claims are issued, and if $I \geq \bar{L}+A_{2}(\bar{L})+$ $\theta \mathrm{A}_{2}(0)$, no fixed long-term claims are issued.

The share of short-term debt in the overall issue, $I^{s} / I$, is increasing in $I$. If $A_{2}$ and $y_{2}$ exhibit nonincreasing returns to scale, the ratio of short-term debt to equity, $I^{s} / I^{e}$, is increasing in $I$.

Proof. From (21)

$$
\frac{d L_{0}^{\star}}{d I}=\frac{1}{1+A_{2}^{\prime}\left(L_{0}\right)+\theta \Delta^{\prime}\left(L_{0}\right)} .
$$


For both (22) and (23) it is then straightforward to check that $d / d I$ $\left(I^{s} / I\right)>0$. If $(23)$ holds, $I^{s} / I^{e}=I^{s} /\left(\theta A_{2}(0)\right)$, which is increasing in $L_{0}^{\star}$, hence in $I$. If (22) holds,

$$
\frac{d}{d L_{0}^{\star}}\left(\frac{I^{s}}{I^{e}}\right)=\frac{\theta}{\left(I^{e}\right)^{2}}\left[\left(-y_{2}^{\prime}\left(L_{0}^{\star}\right) \Pi\left(L_{0}^{\star}\right)-\left(y_{2}(0)-y_{2}\left(L_{0}^{\star}\right)\right) \Pi \Pi^{\prime}\left(L_{0}^{\star}\right)\right],\right.
$$

which is positive if $y_{2}$ and $A_{2}$ are concave.

Figure I summarizes how capital structure changes QED with decreasing profitability of the investment (increasing $I$ ). We do not know of any empirical studies that provide evidence on the relationship between short-term indebtedness and profitability, predicted to be negative. The prediction about $I^{s} / I^{e}$ is consistent with Titman and Wessels [1988], who for a sample of 469 Compustat firms from 1974 to 1982 report a strong and significant negative correlation between profitability and the ratio of shortterm debt levels to market values of equity. ${ }^{18}$

By Propositions 2 and 3, short-term indebtedness $R_{x}$ and liquidation rights $L_{0}^{1}$ comove with increasing $I$. Hence, the impact on the degree of collateralization of short-term debt, $L_{0}^{1} / R_{x}$, is a priori indeterminate. Indeed, it is easily seen that the relationship need not be monotonic. However, when capital requirements are larger, namely if (23) holds, collateralization is always increasing in I. If the project's finance capacity is reached, $L_{0}^{1}=\bar{A}$, and collateralization is 100 percent. $^{19}$

We conclude this section by modifying the model of the previous sections slightly, to provide some insight into how the financing decision is affected by the structure of long-term returns. Let $f(L), 0 \leq L \leq \bar{A}, f^{\prime}<-1$, denote the total long-term returns of a project, divided into private returns $y_{2} \equiv \alpha f$ and public returns $A_{2} \equiv(1-\alpha) f, 0<\alpha<1$. Assumptions 2(4)-(5) then read $-1 / \alpha \geq$ $f^{\prime}>-1 /(1-\alpha)$. By varying $\alpha$ (within these bounds), we can analyze how changes in the composition of long-term returns affect the optimal capital structure. Lower $\alpha$ 's then correspond to a greater degree of tangibility of long-term returns.

18. The findings by Titman and Wessels [1988] must be taken cum grano salis. In particular, they find that the ratio of short-term debt to the book value of equity is more or less uncorrelated with profitability.

19. For Germany the study by Drukarczyk, Duttle, and Rieger [1985] finds that the average degree of collateralization for small- and medium-sized loans is 70 percent and that the key determinants for lowering collateral requirements by banks are project profitability and management quality. 


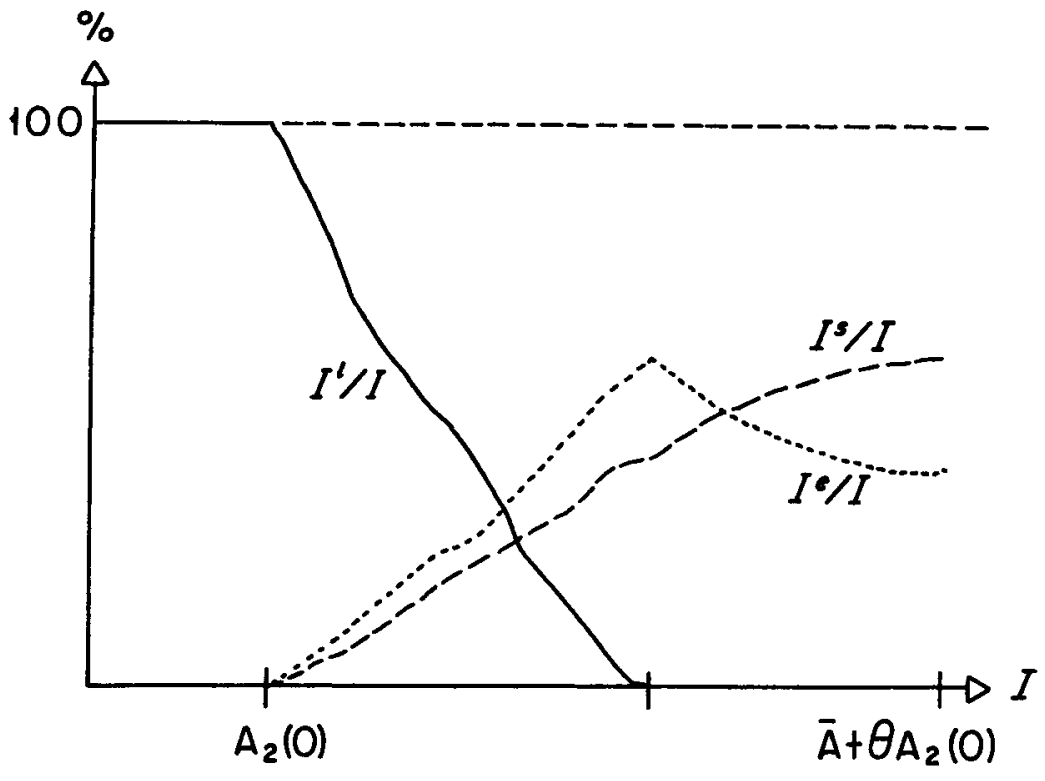

FiguRE I

PROPOSITION 5. The more of total long-term returns is nonverifiable (i.e., the larger $\alpha$ ), the larger is the share of short-term debt in the optimal capital structure.

The proof of Proposition 5 is straightforward. The proposition directly reflects the strategic role of short-term debt in our theory: the less investors expect to participate in the long-term returns of the firm, the more they use short-term leverage to make the firm pay out funds earlier on. This is consistent with the empirical findings on asset tangibility and debt maturity for small U.S. firms as reported by Hart and Moore [1994]. ${ }^{20}$

A broader view obtains if one interprets $\alpha$ as indicative of the size of the firm in the present simple model. In this interpretation small firms are characterized by a relatively high degree of owner discretion and few established control structures, which make returns less readily available to outsiders. Hence, their $\alpha$ is larger. For larger firms with better established control structures and a broader asset base, on the other hand, it is more difficult to divert returns from outsiders; these firms are thus characterized by a

20. Data from several surveys by the U. S. National Federation of Independent Business in the 1980s. 
smaller $\alpha$. This interpretation is consistent with the empirical findings by Jensen, Solberg, and Zorn [1992] and Rajan and Zingales [1994]. ${ }^{21}$

Under this hypothesis, Proposition 5 rationalizes the wellknown empirical regularity that short-term indebtedness decreases with firm size, found in several flow-of-funds statistics. For example, Gertler and Gilchrist [1994] report for the U. S. manufacturing sector (data for 1986) that the share of short-term debt in overall debt declines from 29 percent for small firms (assets $<\$ 50$ million) to 13 percent for large firms (assets $>\$ 1$ billion). Federal Flow of Funds Statistics for Germany [Deutsche Bundesbank 1985], which reports the full balance sheet, shows a short-term debt/asset ratio of 55.9 percent for small firms (assets $<D M 25$ million), declining to 39.5 percent for large firms (assets $>$ DM 25 million).

\section{CONCLUSION}

This article further develops the bargaining-based theory of capital structure pioneered by Hart and Moore [1989, 1991], and Bolton and Scharfstein [1992]. According to this theory, the firm's capital structure influences potential future negotiations between the firm and its investors, and the anticipation of such negotiations, in turn, influences financial decisions. The choice of financial contracts is determined as a trade-off between, on the one hand, the desire to discourage ex post renegotiation (strategic default), and on the other hand, the wish to limit inefficient liquidation when the firm is cash-constrained (liquidity default). This trade-off determines endogenously an optimal cost of financial distress. We demonstrate how investors by separating their claims across time and states of nature can reduce the need for inefficient liquidation in liquidity default while maintaining the disincentives of strategic default. As a result, the firm can reduce its cost of capital and increase its finance capacity.

The whole analysis has been conducted under the assumption that the firm has all the bargaining power in ex post renegotiation. This is an extreme case, since it holds the investors down to their liquidation payoffs and thus the scope for ex post opportunism on the side of the firm is particularly large. Still, the analysis

21. Rajan and Zingales [1994] do not report a regression of firm size on tangibility (only comovements in joint regressions). However, Rajan [1994], using these data, confirms the correlation. 
demonstrates a systematic difference between the commitment possibilities with one or more investors. It is easy to show that that this systematic difference persists under more general allocations of bargaining power; i.e., when the firm's ex post opportunism is more restricted. ${ }^{22}$

Like Bolton and Scharfstein, we emphasize the role of technological factors, or more precisely the effect of liquidation on production, in ex post bargaining. We derive predictions for how these factors affect the choice of debt maturity, the debt-equity mix, and the degree of collateralization. To focus our analysis, we have largely ignored the impact of outside influences on the bargaining problem by assuming the outside valuation of firm assets to be constant. However, our analysis is easily extended to show that, for example, firms with readily redeployable assets, i.e., with high liquidation values, have a higher finance capacity than firms with highly specific assets (cf. Williamson [1988]). Similarly, if the firm has more than one type of verifiable asset, the most attractive collateral for short-term debt are assets with high liquidation values that depreciate quickly (see Berglöf and von Thadden [1994]).

The importance of liquidation values has been emphasized by Shleifer and Vishny [1992], who have argued that the costs of financial distress vary over the business cycle and according to industry-specific factors. In recessions, when asset markets often are relatively illiquid and liquidation values consequently low, the costs of financial distress are higher. In boom periods, liquidity shocks are more likely to be specific to a particular firm and do not affect alternative users of liquidated assets. As a result, the costs of inefficient liquidation are smaller. As argued by Shleifer and Vishny, these cyclical variations will affect a firm's debt capacity, and, we argue, more generally a firm's capital structure.

Conversely, as illustrated by Asquith, Gertner, and Scharfstein [1994], capital structure has an important impact on how firms can deal with (cyclical or firm-specific) financial distress. They show that while underperforming firms are more likely to get into financial distress, it is not necessarily a firm's long-term profitability, but rather its capital structure that determines how it fares once in distress. A better understanding of this interrelation-

22. Only when the firm has no bargaining power ex post is capital structure irrelevant. In this case, outside investors can extract all ex post surplus from the firm by assumption, and devices to improve extraction are not needed. See Berglöf and von Thadden [1994]. 
ship between capital structure and short-term performance may help explain findings such as those by Gertler and Gilchrist [1994] that smaller and medium-sized firms in the United States with their strong dependence on short-term bank finance and limited access to capital markets are much more affected than larger firms by business cycle-related fluctuations. As our comparative statics results show, corporate finance may help to shed light on these macroeconomic issues.

ECARE, Untversité Libre de BRUXelles, Belgium, AND StockHolm School of ECONOMICS

INSTITUT FÜR VOLKSWIRTSCHAFT, UNIVERSITÄT BASEL, SWITZERLAND

\section{REFERENCES}

Aghion, Philippe, and Patrick Bolton, "An 'Incomplete Contracts' Approach to Bankruptcy and the Financial Structure of the Firm," Review of Economic Studies, LIX (1992), 473-94.

Aghion, Philippe, Oliver Hart, and John Moore, "The Economics of Bankruptcy Reform," Journal of Law, Economics and Organization, VIII (1992), 523-46.

Asquith, Paul, Robert Gertner, and David Scharfstein, "Anatomy of Financial Distress: An Examination of Junk Bond Issuers," Quarterly Journal of Economics, CIX (1994), 625-58.

Berglöf, Erik, and Ernst-Ludwig von Thadden, "The Hypothetical Creditor's Bargain and the Determination of Capital Structure," mimeo, Université Libre de Bruxelles, 1994

Bergman, Yaacov, and Jeffrey Callen, "Opportunistic Underinvestment in Debt Renegotiation and Capital Structure," Journal of Financial Economics, XXIX (1991), 137-71.

Bester, Helmut, "The Role of Collateral in a Model of Debt Renegotiation," Journal of Money, Credit and Banking, XXVI (1994), 72-85.

Bolton, Patrick, and David Scharfstein, "A Theory of Secured Debt: Contracting with Multiple Creditors," mimeo, Université Libre de Bruxelles, 1992.

Brown, David, Christopher James, and Robert Mooradian, "Asset Sales by Financially Distressed Firms," mimeo, University of Florida, 1993.

Bulow, Jeremy, and John Shoven, "The Bankruptcy Decision," Bell Journal of Economics, IX (1978), 437-56.

Deutsche Bundesbank, "Annual Accounts of Small and Medium-Sized Enterprises," Monthly Reports, April 1985, pp. 22-29.

Diamond, Douglas, "Bank Loan Maturity and Priority When Borrowers Can Refinance," in Colin Mayer and Xavier Vives, eds., Capital Markets and Financial Intermediation (Cambridge: Cambridge University Press, 1992), pp. 46-80.

Dewatripont, Mathias, and Jean Tirole, "A Theory of Debt and Equity: Diversity of Securities and Manager-Shareholder Congruence," Quarterly Journal of Economics, CIX (1994), 1027-54.

Drukarczyk, Jochen, John Duttle, and Reinhard Rieger, Mobiliarsicherheiten (Köln: Bundesanzeiger, 1985).

Franks, Julian, and Kjell Nyborg, "Workouts versus Formal Bankruptcy: Incentives and Inefficiencies under Different Bankruptcy Codes," mimeo, London Business School, 1993.

Gale, Douglas, and Martin Hellwig, "Repudiation and Renegotiation: The Case of Sovereign Debt," International Economic Review, XXX (1989), 3-31.

Gertler, Mark, and Simon Gilchrist, "Monetary Policy, Business Cycle and the Behavior of Small Business Firms," Quarterly Journal of Economics, CIX (1994), 309-40. 
Gertner, Robert, and David Scharfstein, "A Theory of Workouts and the Effects of Reorganization Law," Journal of Finance, XLVI (1991), 1189-1222.

Gilson, Stuart, Kose John, and Larry Lang, "Troubled Debt Restructurings: An Empirical Study of Private Reorganization of Firms in Default," Journal of Financial Economics, XXVII (1990), 315-53.

Grossman, Sanford, and Oliver Hart, "Takeover Bids, the Free Rider Problem, and the Theory of the Corporation,"Bell Journal of Economics, XI (1980), 42-64.

Harris, Milton, and Artur Raviv, "The Design of Bankruptcy Procedures," mimeo, University of Chicago, 1991.

Harris, Milton, and Artur Raviv, "Financial Contracting Theory," in Jean-Jacques Laffont, ed., Advances in Economic Theory, Vol. II (Cambridge: Cambridge University Press, 1992), pp. 64-150.

Hart, Oliver, "Theories of Optimal Capital Structure: The Managerial Discretion Perspective," in Margaret Blair, ed., The Deal Decade. What Takeovers and Leveraged Buyouts Mean for Corporate Governance (Washington, DC: The Brookings Institution, 1993), pp. 19-53.

Hart, Oliver, and John Moore, "Default and Renegotiation: A Dynamic Model of Debt," mimeo, London School of Economics, 1989.

Hart, Oliver, and John Moore, "Debt and Seniority: An Analysis of the Role of Hard Claims in Constraining Management," mimeo, London School of Economics, 1993.

Hart, Oliver, and John Moore, "A Theory of Debt Based on the Inalienability of Human Capital," Quarterly Journal of Economics, CXX (1994), 840-79.

Jensen, Gerald, Donald Solberg, and Thomas Zorn, "Simultaneous Determination of Insider Ownership, Debt, and Dividend Policies," Journal of Financial and Quantitative Analysis, XXVII (1992), 247-63.

Perotti, Enrico, and Kathryn Spier, "Capital Structure as a Bargaining Tool: The Role of Leverage in Contract Renegotiation," American Economic Review, LXXXIII (1993), 1131-41.

Rajan, Raghuram, personal communication, March 1994.

Rajan, Raghuram, and Luigi Zingales, "What Do We Know about Capital Structure? Some Evidence from International Data," mimeo, University of Chicago, 1994.

Rubinstein, Ariel, and Asher Wolinsky, "Renegotiation-Proof Implementation and Time Preferences," American Economic Review, LXXXII (1992), 600-14

Shleifer, Andrei, and Robert Vishny, "Liquidation Values and Debt Capacity: A Market Equilibrium Approach," Journal of Finance, XLVII (1992), 1343-66.

Titman, Sheridan, and Roberto Wessels, "The Determinants of Capital Structure Choice," Journal of Finance, XLIII (1988), 1-19.

Wells, Robin, "Strategic Debt," mimeo, University of Southampton, 1992.

Williams, Joseph, "Monitoring and Optimal Financial Contracts," mimeo, University of British Columbia, 1989.

Williamson, Oliver, "Corporate Finance and Corporate Governance," Journal of Finance, XLIII (1988), 567-91.

Winton, Andrew, "Costly State Verification and Multiple Investors: The Role of Seniority," mimeo, Kellogg School of Management, Northwestern University, 1990.

Zender, Jaime, "Optimal Financial Instruments," Journal of Finance, XXVI (1991), 1645-65. 